\title{
Comparison of Word-Writing Performance according to the Degree of Cognitive Decline: Focused on Patients with Subjective Memory Complaint, Mild Cognitive Impairment, and Alzheimer's Disease
}

\author{
Han Sol Lee ${ }^{1}$, Eun Byeol Cho², Duk L. Na ${ }^{2,3,4,5}$, Ji Hye Yoon ${ }^{6}$ \\ 'Department of Speech Pathology, Graduate School of Health Sciences, Hallym University, Chuncheon, Korea \\ ${ }^{2}$ Department of Neurology, Samsung Medical Center, Sungkyunkwan University School of Medicine, Seoul, Korea \\ ${ }^{3}$ Neuroscience Center, Samsung Medical Center, Seoul, Korea \\ ${ }^{4}$ Department of Health Sciences and Technology, Samsung Advanced Institute for Health Sciences \& Technology, Sungkyunkwan University, Seoul, Korea \\ ${ }^{5}$ Samsung Alzheimer Research Center, Samsung Medical Center, Seoul, Korea \\ ${ }^{6}$ Division of Speech Pathology and Audiology, College of Natural Sciences, Hallym University, Chuncheon, Korea
}

\author{
Received: October 19, 2020 \\ Revised: November 16, 2020 \\ Accepted: November 17, 2020 \\ Correspondence: \\ Ji Hye Yoon, PhD \\ Division of Speech Pathology and \\ Audiology, College of Natural Sciences, \\ Hallym University, 1 Hallymdaehak-gil, \\ Chuncheon 24252, Korea \\ Tel: +82-33-248-2224 \\ Fax: +82-33-256-3420 \\ E-mail: j.yoon@hallym.ac.kr
}

\begin{abstract}
Purpose: Writing deficits are one of the major indicators of cognitive decline. The purpose of this study was to investigate the word-writing performance according to the degree of cognitive decline. Methods: Eighty-seven participants [30 patients with subjective memory complaint (SMC), 30 patients with amnestic mild cognitive impairment (aMCI), and 27 patients with Alzheimer's disease (AD)] performed tasks involving writing regular words, irregular (phoneme-grapheme non correspondent) words, and nonwords. Data were collected using a tablet personal computer and digital pen and were analyzed according to four categories: the number of the correct response, error types, graphemic writing time, and pause time. Results: There was no difference between the SMC group and the $\mathrm{aMCl}$ group regardless of the writing task types, whereas the AD group scored significantly lower compared with the aMCI group in the irregular word-writing task. Additionally, all three groups showed poor performance in the order of regular words, nonwords, and irregular words. The most frequent error types in all three groups were substitution, elision, and addition. There was no difference in the graphemic writing time and pause time. Conclusion: Our findings show that declined cognitive function may affect the lexical route during writing. This study is meaningful because it is the first attempt to investigate the word-writing performance according to the degree of the neuropathological deficits.
\end{abstract}

Key Words: Alzheimer's disease, Mild cognitive impairment, Subjective memory complaint, Writing route.

\section{INTRODUCTION}

인지기능장애(cognitive impairment)란, 기억력, 언어 능력, 지남력, 판단력 등의 다양한 영역의 인지기능이 저하되는 것을 의미하며, 치매(dementia)는 뇌의 퇴행성 변화에 의하여 위와 같은 인지기능이 저하되면서 일상생활능력에 어려움을 보이는 증상이다. 치매의 원인 질환 중 가장 큰 비율을 차지하는 알츠 하이머병(Alzheimer's disease, AD)은 대뇌 피질에 타우(tau) 와 베타 아밀로이드(amyloid- $\beta, A \beta$ ) 단백질이 축적되어 신경세

(c) This is an Open Access article distributed under the terms of the Creative Commons Attribution Non-Commercial License (https://creativecommons.org/licenses/by-nc/4.0) which permits unrestricted non-commercial use, distribution, and reproduction in any medium, provided the original work is properly cited.
포가 손상되면서 점진적으로 인지기능의 저하가 진행되는 신경 퇴행성질환에 속한다.

$\mathrm{AD}$ 환자는 질환의 초기부터 양측 측두엽(temporal lobe) 및 전두엽(frontal lobe)의 손상으로 인하여 기억력 문제와 더불어 언어 능력의 저하가 나타난다. 이러한 언어 능력 저하는 질환이 진행되면서 구어 능력(spoken language)뿐만 아니라(Huff et al., 1986), 읽기(reading)나 쓰기(writing)와 같은 문어 능력 (written language)에도 영향을 미친다(Yoon et al., 2011, 2012). 문어는 구어를 기초로 습득되는 고차원의 언어 능력이 며(Paul \& Norbury, 2012), 특히 쓰기는 철자나 의미 등의 언어 능력과 더불어 주의력, 작업 기억, 시공간 능력 등의 다양한 인 지기능의 상호작용으로 이루어지는 복잡한 인지 활동으로 
(Kim, 2012), 쓰기를 수행하는 과정에서의 어려움을 지칭하는 실서증(agraphia)은 뇌손상으로 인하여 인지기능 저하가 나타 나는 환자에게 빈번히 발생할 수 있어서 인지기능 감퇴를 민 감하게 반영하는 주요 지표 중 하나로 보고되었다(Yoon et al., 2006).

쓰기 수행은 대뇌에 저장된 철자 지식을 활용하는 단계와 손 의 움직임을 통한 운동학적 단계를 차례로 거치면서 수행되는 데, 철자 지식을 활용하는 단계에서는 다음의 두 가지 통로를 활용하게 된다. 먼저 내부철자사전(graphemic output lexicon) 에 저장된 친숙한 단어(familiar word)는 자소와 음소의 불일 치성(irregularity)이나 애매성(ambiguity)에 상관없이 저장된 단어의 철자를 선택하는 어휘 통로(lexical route)를 활성화하 여 철자 쓰기가 수행된다. 반면, 비단어(nonword) 혹은 처음 들어보는 익숙하지 않은 단어(unfamiliar word)의 경우 음소 와 대응되는 자소를 선택하는 음운 통로(phonological route) 를 활성화하여 철자 쓰기가 수행된다. 그간 $\mathrm{AD}$ 환자를 대상으 로 진행된 질환의 중증도에 따른 실서증 양상을 확인한 연구 (Rapcsak et al., 1989)를 살펴보면, 초기 $\mathrm{AD}$ 환자의 경우 규칙 단어(regular word)나 비단어 쓰기에 비해 불규칙 단어(irregular word) 또는 음소-자소 불일치 단어(phoneme-grapheme noncorrespondent word)에서 수행력이 저하되는 것이 관찰되 었다. 이러한 결과는 초기 $\mathrm{AD}$ 의 경우 쓰기 수행 시 단어의 의 미적인 지식을 처리하는 어휘 통로가 손상됨에 따라 상대적으 로 보존되어 있는 음소와 자소를 일대일로 처리하는 음운 통로 에 의존하여 쓰기를 수행하기 때문에 어휘 실서증이 나타나는 것으로 해석되었다. 중기 $\mathrm{AD}$ 의 경우에는 불규칙 단어에서의 오류뿐만 아니라 비단어에서도 오류가 나타났으며, 후기 $\mathrm{AD}$ 의 경우 음운 통로마저 손상됨에 따라 음운 실서증의 양상도 보고 되었다. 이러한 연구들의 결과를 종합하면 $\mathrm{AD}$ 환자의 쓰기 수 행력 양상은 불규칙 단어에서 음운적으로 적절한 오류를 보이 는 초기 단계, 비단어에서 음운적으로 부적절한 오류를 보이는 중간 단계, 단어 조건과 상관없이 오류를 보이는 후기 단계로 구분할 수 있다.

$\mathrm{AD}$ 에 대한 조기 감별 및 중재의 중요성이 부각됨에 따라 경 도인지장애(mild cognitive impairment, $\mathrm{MCI}$ ) 또한 주목을 받 고 있다. $\mathrm{MCI}$ 는 인지기능은 저하되지만 일상생활능력의 지장 이 없는 상태로 $\mathrm{AD}$ 의 전임상적(preclinical) 단계에 해당하며, 매년 10 15\%의 $\mathrm{MCI}$ 환자가 $\mathrm{AD}$ 로 진행되고, 6년간 약 $80 \%$ 의 환자가 $\mathrm{AD}$ 로 진단된다(Petersen et al., 1999). 결함을 보이는 인지기능 장애의 양상에 따라 $\mathrm{MCI}$ 의 하위유형을 나눌 수 있 으며, 이 중 기억력 장애가 다른 인지기능에 비하여 두드러지는 기억성 경도인지장애(amnestic mild cognitive impairment, $\mathrm{aMCI}$ 는 $\mathrm{AD}$ 로 전이될 가능성이 가장 높기 때문에(Petersen et al., 1999), aMCI 환자에 대한 임상적 중요성이 높아지고 있 다. 더불어 고령화(aging)가 급속히 진행됨에 따라 주관적 기억 호소(subjective memory complaint, $\mathrm{SMC}$ ) 환자에 관한 연구 도 활발히 진행되고 있다. $\mathrm{SMC}$ 환자들은 객관적인 신경심리검 사에서 정상 범주의 수행력을 보이지만, 스스로 본인의 기억력 감퇴를 호소한다. 국내 선행연구에 따르면 스스로 기억력이 저 하되었다고 호소하는 환자는 60 세 이상에서 $60 \%$ 정도로 보고 되었으며(Kang \& Baek, 2014), 이들은 기억력 저하를 호소하 지 않는 집단보다 $\mathrm{MCI}$ 나 $\mathrm{AD}$ 로 진행될 가능성이 더 높다는 결 과가 발표되었다(Song \& Kang, 2011). ‘한국인의 건강과 노화에 대한 전향적 연구(Korean Longitudinal Study on Health and Aging, KLoSHA)' 자료(Ryu et al., 2007)에 따르면 위 연구에 참여한 747명의 우리나라 노인 중 약 $21.3 \%$ 가 $\mathrm{SMC}$ 로 확인되 었다. 또한 $\mathrm{SMC}$ 환자의 사후 부검을 통해 대뇌피질에서 타우나 베타 아밀로이드 단백질의 침착을 확인한 연구(Barnes et al., 2006)에서는 SMC가 호소하는 인지기능의 저하소견이 치매에 서 나타나는 신경병리학적 변화와 관련이 있을 가능성을 제시 하면서 $\mathrm{MCI}$ 이전 단계에서부터 관심을 가질 것을 역설하였다. 이렇게 증상이 경미한 전임상적 단계에서 $\mathrm{AD}$ 로 이환될 가능성 이 높은 환자를 조기에 발견하여 병의 악화를 예방하거나 지연 시키는 것은 사회적·경제적인 측면에서 막대한 부담을 줄일 수 있는 중요한 요점이다.

이렇게 $\mathrm{AD}$ 를 예측하기 위해서는 언어적 측면에서도 $\mathrm{SMC}$ 나 $\mathrm{MCI}$ 환자의 수행력을 확인하는 것이 도움이 될 수 있으나 $\mathrm{MCI}$ 환자와 $\mathrm{SMC}$ 환자의 쓰기 수행력에 관한 연구는 국내외를 막 론하고 상당히 부족한 실정이다. 국외 $\mathrm{aMCI}$ 환자에게 문장을 대문자로 쓰기 및 대문자 ‘ $\mathrm{T}$ '를 반복하여 쓰기 과제를 시행한 후 쓰인 문장의 너비 및 높이, 쓰기 속도 및 쉼 시간을 측정한 연구(Kawa et al., 2017)에서는 모든 쓰기 과제에서 aMCI 환자 가 정상 대조군에 비하여 전체 문장의 높이가 큰 것으로 나타 났으며, 쓰기 속도 및 심 시간이 느린 것으로 나타났다. 그러나 이러한 연구는 동일한 글자를 반복하여 쓰면서 나타나는 손의 움직임과 속도를 측정하였으므로 쓰기 처리 과정 중 철자 단계 이후의 운동학적 단계에 보다 초점을 맞추었으며 인지적인 처 리 능력과 보다 관련이 있는 철자 단계의 쓰기 통로 및 처리 과 정을 확인하기에는 부족함이 있었다.

또한 쓰기라는 활동은 위와 같은 언어적 능력(철자 처리 과 정)이 손의 운동을 통해 구현될 때 시공간적 형태를 가진 글자 로 표현된다는 점에서 고유한 문자 체계의 특성이 반영될 수 있다. 특히 우리나라의 한글은 영어권의 알파벳과 비교하여 시 공간적인 측면에서 특수성이 두드러진다. 한글은 사각형의 음 절 형태 안에서 각 자소가 공간적인 규칙성을 가지고 초성, 중 성, 종성으로 조합되는 모아쓰는 형식을 취한다. 방향에 따라 
자소가 왼쪽에서 오른쪽 방향의 가로로 배열되는 횡단쓰기(예: 사), 자소가 위에서 아래 방향의 세로로 배열되는 종단쓰기(예: 귤), 횡단쓰기와 종단쓰기가 혼합되어 있는 종횡단 혼합쓰기 (예: 콴)로 분류할 수 있다(Yoon et al., 2006). 이러한 맥락에서 알파벳이 횡단쓰기의 형태로만 배열되는 것과는 달리, 한글에 서는 음절 쓰기를 하면서 음절의 구성과 자소의 배치에도 시공 간적인 조절이 필요하므로 초성, 중성, 종성의 글자를 직접 쓰는 시간이나 초성과 중성 사이, 중성과 종성 사이에 머무르는 시간 등에서도 다양한 양상이 나타날 수 있으므로, 철자적 측면뿐만 아니라 시공간적 측면의 심리-운동적 쓰기 양상을 함께 확인 하는 것이 필요하다.

이에 본 연구는 인지기능 감퇴 정도에 따른 쓰기 능력의 변 화를 확인하기 위하여 $\mathrm{SMC}, \mathrm{aMCI}$ 및 $\mathrm{AD}$ 환자를 대상으로 규칙 단어, 불규칙 단어, 비단어 쓰기를 시행하였으며, 한글의 언어 및 시공간적인 특성을 모두 고려하여 다음과 같은 측면에 서 쓰기 수행력을 분석하였다. 첫째, 언어적인 측면에서 단어 조건(규칙 단어, 불규칙 단어, 비단어)에 따른 정반응 점수와 오류 유형을 살펴보았다. 둘째, 시공간적인 측면에서 초성, 중 성, 종성으로 이루어진 1 음절 단어의 쓰기 시간 및 쉼 시간을 살펴보았다.

\section{MATERIALS AND METHODS}

\section{연구 대상}

본 연구에는 만 50 90세 사이의 남녀 중 다음 선정 기준에 맞는 $\mathrm{SMC}$ 환자 30 명, $\mathrm{aMCI}$ 환자 30 명, $\mathrm{AD}$ 환자 27 명, 총 87 명이 참여하였다. 모든 대상자는 삼성서울병원 신경과에 외래 로 내원하여 신경과 전문의로부터 신경학적 진찰, 병력, 인지기 능 검사 결과를 바탕으로 진단된 환자들이었다.

$\mathrm{SMC}$ 환자의 자세한 선정 기준은 다음과 같다: 1) 건강선별 설문지(Christensen et al., 1991)를 실시하여 정신적, 신경학적, 신체적 질환의 병력이 없으나, 2) 주관적으로 기억력 저하를 호 소하여 내원한 자로, 3) 서울신경심리검사 2판(Seoul Neuropsychological Screening Battery-Second Edition, SNSB-II) (Kang et al., 2012)을 실시하여 연령 및 교육년수에 해당하는 규준에서 인지기능이 모든 영역에서 $16 \%$ ile 이상으로 정상 범 주로 판단되며, 4) Seoul-Instrumental Activities of Daily Living (S-IADL) (Ku et al., 2004)에서 8점 미만으로 일상생활 능력에 문제가 없고, 5) 단축형 노인 우울 척도(Short Form Geriatric Depression Scale, SGDS) (Kee, 1996)를 실시하여 8점 이하로 우울감이 없는 환자를 대상으로 하였다.

$\mathrm{aMCI}$ 환자는 Petersen(2004)의 진단기준에 따라 기억성 경 도인지장애로 진단된 환자를 선정하였으며, 자세한 선정 기준
은 다음과 같다: 1) 건강선별설문지(Christensen et al., 1991)를 실 시하여 정신적, 신경학적, 신체적 질환의 병력이 없으며, 2) SGDS (Kee, 1996)를 실시하여 8점 이하로 우울감이 없고, 3) SNSBII (Kang et al., 2012)를 실시하여 연령 및 교육년수에 해당하는 규준에서 언어적 기억력 검사(Seoul Verbal Learning Test, SVLT) (Kang \& Na, 2003)의 지연회상(delayed recall) 점수 또는 비 언어적 기억력을 확인하는 Rey Figure Test의 지연회상 점수가 $16 \%$ ile 미만에 해당하며, 4) S-IADL (Ku et al., 2004)에서 8점 미만으로 일상생활능력에 문제가 없고, 5) 치매 기준에 해당하 지 않는 환자를 대상으로 하였다.

$\mathrm{AD}$ 환자는 후기발현 $\mathrm{AD}$ (late onset Alzheimer's disease, $\mathrm{LOAD}$ 로 진단된 환자를 선정하였으며, 자세한 선정기준은 다 음과 같다: 1) National Institute of Neurological and Communicative Disorders and Stroke-Alzheimer's Disease and Related Disorders Association (NISCDDS-ADRDA)의 probable AD 기준(Dubois et al., 2007)을 만족하며, 2) SNSB-II (Kang et al., 2012)를 실시하여 연령 및 교육년수에 해당하는 규준에서 $16 \%$ ile 미만에 해당하며, 3) S-IADL (Ku et al., 2004) 에서 8점 이상으로 일상생활에 지장이 있고, 4) 증상의 발현이 65세 이후에 시작되었으며, 5) 임상치매척도(clinical dementia rating scale, CDR)가 1 인 환자를 대상으로 하였다.

대상자 제외기준은 다음과 같다: $\mathrm{SMC}$ 집단, $\mathrm{aMCI}$ 집단, $\mathrm{LOAD}$ 집단 모두 1) 한국어를 모국어로 사용하지 않는 경우, 2) 왼손잡이인 경우, 3) 초등학교 졸업 학력 미만인 경우, 4) 과 거에 뇌손상 및 기타 신경학적 병력이 있는 경우, 5) 과제 수행 이 불가능할 정도의 청력과 시력을 가지고 있는 경우, 6) 오른 쪽 상지(upper limbs) 편마비(hemiplegia)가 있는 경우는 대상 자에서 제외하였다.

Table 1에 나타난 바와 같이 세 집단의 연령, 교육년수, 한국 판 간이정신상태 검사(Korean-Mini Mental State Examination, K-MMSE) (Kang \& Na, 2003) 점수, SGDS 점수의 차이 가 유의미한지 알아보기 위해 분산분석을 실시한 결과, 세 집단 의 교육년수 $\left(\mathrm{F}_{(2,86)}=0.178, p=0.837\right)$ 는 통계적으로 유의미한 차 이가 없었으나, 연령 $\left(\mathrm{F}_{(2,86)}=8.905, p<0.001\right), \mathrm{K}-\mathrm{MMSE}$ 점수 $\left(\mathrm{F}_{(2,86)}=68.958, p<0.001\right), \mathrm{SGDS}$ 점수 $\left(\mathrm{F}_{(2,86)}=121.072, p<\right.$ 0.001)는 통계적으로 유의미한 차이가 나타났다. 사후분석을 실시한 결과, 연령은 $\mathrm{SMC}$ 와 $\mathrm{aMCI}(p=0.314)$ 는 유의미한 차 이가 없었으나, $\mathrm{SMC}$ 와 $\mathrm{AD}(p<0.001), \mathrm{aMCI}$ 와 $\mathrm{AD}(p=$ $0.020)$ 는 유의미한 차이가 나타나 $\mathrm{AD}$ 집단과의 연령 차이가 있는 것으로 나타났다. $\mathrm{K}-\mathrm{MMSE}$ 점수는 $\mathrm{SMC}$ 와 $\mathrm{aMC}(p<$ $0.001), \mathrm{SMC}$ 와 $\mathrm{AD}(p<0.001), \mathrm{aMCI}$ 와 $\mathrm{AD}(p<0.001)$ 모두 차이가 나타나 인지기능 감퇴에 따라 집단의 차이가 있는 것으 로 나타났다. SGDS 점수는 모든 집단에서 절단점 이하로 관찰 
Table 1. Participants' characteristics

\begin{tabular}{lcccc}
\hline & SMC $(\mathrm{n}=30)$ & aMCI $(\mathrm{n}=30)$ & $\mathrm{AD}(\mathrm{n}=27)$ & $\mathrm{F}$ \\
\hline Age & $69.77(9.096)$ & $73.03(10.351)$ & $79.33(5.463)$ & $8.905^{* * *}$ \\
Education & $12.07(4.008)$ & $12.47(4.265)$ & $12.70(3.989)$ & 0.178 \\
K-MMSE & $29.07(1.048)$ & $25.23(2.661)$ & $21.30(3.314)$ & $68.958^{* * *}$ \\
SGDS & $2.10(0.403)$ & $2.97(0.183)$ & $4.22(0.801)$ & $121.072^{* * *}$ \\
\hline
\end{tabular}

Values are presented as mean (SD). ${ }^{* * *} p<0.001$. SMC: subjective memory complaint, aMCI: amnestic mild cognitive impairment, AD: Alzheimer's disease, K-MMSE: Korean-Mini Mental State Examination, SGDS: Short Form Geriatric Depression Scale

되었으나 $\mathrm{SMC}$ 와 $\mathrm{aMCI}(p<0.001), \mathrm{SMC}$ 와 $\mathrm{AD}(p<0.001)$, $\mathrm{aMCI}$ 와 $\mathrm{AD}(p<0.001)$ 집단 간 차이를 보여 인지기능 감퇴 에 따라 우울감을 더 많이 호소하는 것으로 나타났다.

\section{연구 장비}

본 연구의 검사 도구는 쓰기 수행력의 기기적 측정을 위하여 12인치 $(30.37 \mathrm{~cm}$ )의 태블릿 PC '갤럭시북 12.0 (Galaxy Book 12.0, SM-W720NZKAKOO; Samsung, Suwon, Korea)'과 쓰 기 시간 및 쉼 시간을 측정할 수 있는 소프트웨어를 자체 개발 하여 사용하였다. 펜은 "노리스 디지털(Noris Digital, GP-U999 ERIPAAB; Staedtler, Nuremberg, Germany)'을 사용하였다. 이 펜은 실제 연필과 유사하며, 태블릿 PC 화면에 손이 닿아도 이를 인식하지 않는 팜 리젝션(palm rejection) 기술이 적용되어 태블릿 $\mathrm{PC}$ 의 사용경험이 적은 장노년층도 실제 쓰기 환경과 유 사하게 화면에 손을 댄 체로 쓰기 과제를 수행할 수 있어 어렵 지 않다.

\section{연구 도구}

본 연구에서는 인지기능 변화에 따른 쓰기의 철자적 특성을 살펴보기 위해 의미 및 규칙성에 따라 다음과 같이 과제를 구 성하였다. 의미가 있는 단어이며 자소와 음소가 일대일로 대응 하여 글자와 소리가 일치하는 규칙 단어 8개, 의미가 있는 단어 이며 글자와 소리가 일치하지 않고 음운변동이 적용되는 불규 칙 단어 8 개, 의미가 없는 단어이며 자소와 음소가 일대일로 대 응하여 글자와 소리가 일치하는 비단어 8 개, 총 24 개의 단어를 선정하였다(Appendix 1). 단어 선정 기준은 『현대 국어 사용 빈도 조사 2』 (National Institute of Korean Language; Kim, 2005)를 참고하여 총 82,501개의 일반 어휘 통계 중 빈도순으 로 정렬한 후, 사용 빈도가 적은 저빈도 단어 중에서도 상위 $40 \%$, 하위 $40 \%$ 에 해당하는 규칙 단어와 불규칙 단어를 선정 하였다. 불규칙 단어의 음운변동은 『표준발음실태조사 $3_{\Perp}\left(\mathrm{Na}^{-}\right.$ tional Institute of Korean Language; Choi, 2004), "한국어 어 휘 교육 연구』(Jo, 2000), 『우리말 소리의 체계』(Shin \& Cha, 2003)를 참고하여 선정하였다. 음운변동의 분포를 살펴보면 경 음화, 자음군 단순화, 평폐쇄음화, 격음화, 유음화, 구개음화 순
으로 빈도 및 백분율이 높았으므로 높은 빈도의 음운변동을 포함하되 난이도를 통일하기 위하여 두 개의 자소가 변동되는 음운변동만을 포함하였다. 이에, 다른 음운변동은 공통적으로 두 개의 자소가 변동되거나 탈락되지만(예: 법률[범뉼]) 유음화 의 경우 자소 한 개만 변동되기 때문에(예: 혼란[홀란]) 유음화 를 제외한 5 개(경음화, 자음군 단순화, 평폐쇄음화, 격음화, 구개 음화)의 음운변동이 포함된 단어로 선정하였다. 모든 단어들은 음절 길이에 따라 수행력의 차이가 나타날 수 있으므로(Nam et al., 1997) 단어의 길이는 1 3음절로 통제하였으며, 한글의 시공간적 특성인 종단(예: 용), 횡단(예: 사), 종횡단 혼합(예: 콴) 방향의 자소 배열이 세 가지 단어 조건에 균등하게 포함되 어 있도록 구성하였다. 특히 시공간적 측면에서 살펴보기 위하 여 쓰기 시간 및 쉼 시간 측정을 위한 1음절 단어의 경우 한글 의 시공간적 특성이 투영되도록 초성, 중성, 종성으로 이루어지 며 단어 조건당 종단 및 종횡단 혼합의 자소 방향이 균등하게 배열될 수 있도록 구성하였다. 더불어 인지기능이 떨어지면서 이중모음을 쓰는 데 어려움을 보인다는 점을 고려하여(Yoon et al., 2012) 기존의 쓰기 검사도구에서 항목이 상대적으로 부족 했던 음향음성학적 및 형태적으로 복잡한 이중모음이 포함된 단어를 포함하였다.

\section{연구 절차}

본 연구는 조용하고 독립된 공간에서 개별적으로 진행하였 다. 이후 선별검사(건강선별설문지, K-MMSE, SGDS)를 실시하 여 기준에 부합하는 대상자를 선별하였다. 선정 기준에 적합하 다고 판단된 대상자는 단어 쓰기 과제를 실시하였다. 단어 쓰 기 과제는 연구자가 불러주는 24 개의 단어를 듣고 태블릿 PC 화면에 받아쓰도록 하였다. 단어를 불러주는 순서는 모든 대상 자에게 동일하게 제시하였으며, 비단어를 제외한 모든 의미 단 어는 동음이의어(예: 몫[목], 목[목])가 존재하는 등 대상자의 혼 란을 야기할 수 있어 의미단서(예: “짐승을 꾀어 잡는 도구입니 다.”) 또는 예문(예: “몫을 나누다 할 때 ‘몫입니다.”)을 제시하였 다. 단어 제시 후 대상자가 모르겠다고 의사를 표시하거나, 의 사 표시는 없으나 단어 제시 후 15 초 이상 반응이 없을 경우 무 반응(no response)으로 기록하고 다음 단어로 넘어갔으며, 자 
가수정을 한 경우에는 마지막 반응을 채택하였다.

\section{자료 분석}

수집된 자료는 정오반응, 오류 유형, 쓰기 시간 및 쉼 시간을 분석하였다. 정오반응은 정반응 1점, 오반응 0점으로 채점하여 각 단어 조건별 8점, 총 24점으로 점수를 산정하였다. 오류 유 형은 다음의 분류 기준에 따라 자소 수준에서의 오류와 단어 수준에서의 오류로 나누어 살펴보았다. 첫 번째로, 자소 수준 의 오류는 모든 단어 조건에서 시행하였으며 목표 자소가 아닌 다른 자소로 대치(substitution)하거나, 목표 자소를 생략(elision)하거나, 목표 외의 자소를 첨가(addition)하는 경우와 그 외의 자소가 아닌 그림 등을 첨가하는 기타 오류, 단어 제시 후 15 초가 지날 때까지 아무 반응을 보이지 않는 경우와 모르겠다 고 의지를 표현하는 경우를 무반응으로 분류하였다. 두 번째 로, 단어 수준의 오류는 오류를 보일 수 있는 경우에 근거하여 불규칙 단어와 비단어에서 시행하였으며 불규칙 단어에서는 음운변동이 적용된 소리 나는 대로 쓴 오류(phonologically plausible error, PPE) (예: 맏형 $\rightarrow$ 마텽)와 소리 나는 대로 쓰지 않은 오류(phonologically implausible error, PIE) (예: 맏형 $\rightarrow$ 맛현)로 분류하여 오류 유형을 살펴보았다. 비단어에서는 목표 단어와 유사한 어휘로 대치하는 어휘화(lexicalization) 오류 (예: 고돈 $\rightarrow$ 고동)와 목표 단어가 아닌 비단어(예: 고돈 $\rightarrow$ 고똔)를 쓴 오류를 분류하여 오류 유형을 살펴보았다.

쓰기 시간(graphemic writing time, G)은 태블릿 PC 화면에 펜이 닿은 시점부터 펜을 뗀 시점까지 측정되는 한 획을 쓰는 소요시간(duration)으로 초성(G1), 중성(G2), 종성(G3)의 시간 을 산정하였다. 초성과 중성, 중성과 종성, 또는 모든 획을 이어 쓴 경우는 분석에서 제외하였다. 심 시간(pause time, P)은 초 성과 중성 사이의 쉼 시간을 $\mathrm{P} 1$, 중성과 종성 사이의 쉼 시간을
$\mathrm{P} 2$ 로 하여 펜을 뗀 시점부터 다음 획을 쓰기 전까지 측정되는 시간으로 산정하였다. 쓰기 시간과 쉼 시간의 경우 선행연구에 따라 쓰기 수행의 시간적인 측면에 보다 초점을 맞추기 위하여 초성, 중성, 종성이 모두 포함된 1음절 단어에서만 측정하였다. 쓰기 시간 및 쉼 시간의 분석 예시는 Yoon et al.(2018)의 논문 을 참고하여 수정하였다(Figure 1).

\section{통계 분석}

연구 결과는 SPSS version 25.0 (IBM Corp., Armonk, NY, USA) 소프트웨어를 이용하여 분석하였다. 첫 번째로, 집단 간 독립변수인 세 그룹(SMC, $\mathrm{aMCI}, \mathrm{AD}$ )과 집단 내 독립변수인 단어 조건(규칙 단어, 불규칙 단어, 비단어)이 종속변수인 정반 응, 쓰기 시간(G1, G2, G3), 쉼 시간(P1, P2)에 미치는 영향을 확인하기 위해 세 집단 간 유의미하게 차이 나는 연령, $\mathrm{K}-$ MMSE 점수, SGDS 점수 중 연령 변수만 공변량으로 통제하 여 공분산분석(analysis of covariance, ANCOVA)을 실시하였 다. 연령은 노화로 인하여 종속변수(정반응 점수, 오류 유형, 쓰 기 시간, 심 시간)에 영향을 끼칠 수 있는 외제변수라고 판단하 여 공변량으로 통제하였으나, K-MMSE 점수는 독립변수인 세 집단의 인지기능 감퇴 정도를 반영하며 쓰기 수행력 저하의 원 인이 되는 변수로 판단하여 통제하지 않았다. 우울은 인지기능 과 매우 밀접한 연관을 가지며 인지기능의 감퇴 정도가 높을수 록 SGDS 점수가 높아지는 경향을 보이는데(Kim \& Jung, 2007), 이렇게 공변량으로 통제할 변수가 종속변수와 높은 상 관을 보이는 경우 공분산분석의 결과가 왜곡될 수 있으므로 (Miller \& Chapman, 2001) 연구 목적에 부합하는 결과를 도 출하기 위하여 통제하지 않았다. 사후분석할 필요가 있을 경우 집단 간의 차이는 일원배치 분산분석[one-way analysis of variance (ANOVA)] 및 Tukey 사후검정(post-hoc compari-

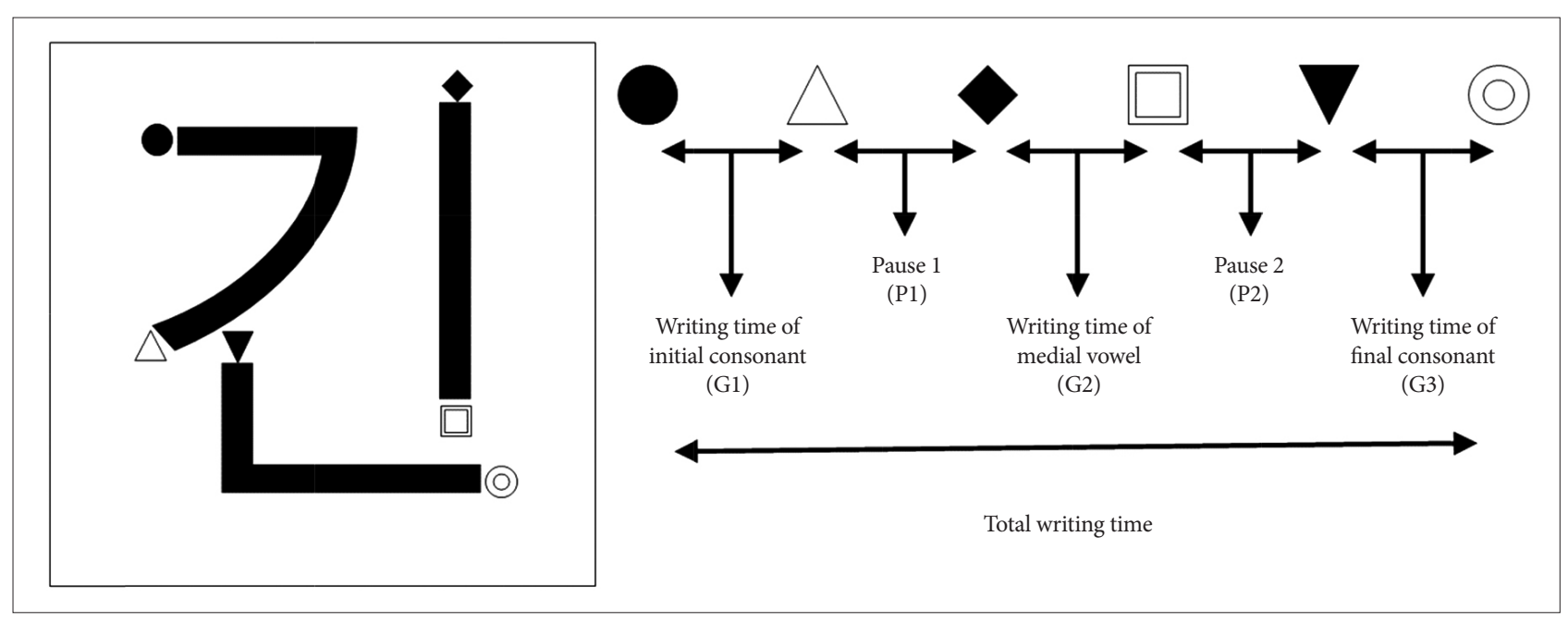

Figure 1. Example of measuring writing time and pause time. G: graphemic writing time, P: pause time. 
son), 집단 내의 차이는 대응표본 $t$-검정(paired $t$-test)을 실시 하였다. 두 번째로, 세 집단의 오류 유형을 확인하기 위해 일원 배치 분산분석(one-way ANOVA)을 실시하고, 사후분석할 필 요가 있을 경우 Tukey 사후검정(post-hoc comparison), 집단 내의 차이는 대응표본 $t$-검정(paired $t$-test)을 실시하였다. 모 든 통계분석은 유의수준 0.05 를 기준으로 하였다.

\section{RESULTS}

\section{집단 간 단어 조건별 정반응 점수 비교}

총 정반응 점수를 살펴보면 $\mathrm{SMC}$ 평균 18.33(SD 4.310), $\mathrm{aMCI}$ 평균 16.30(SD 4.458), $\mathrm{AD}$ 평균 13.41(SD 3.331)로 인지 기능 감퇴에 따라 $\mathrm{SMC}>\mathrm{aMCI}>\mathrm{AD}$ 순으로 집단 간 정반 응 점수의 차이가 있는 것으로 나타났다(Table 2). 이러한 결과 가 유의미한지 살펴본 결과, 집단 간 총 정반응 점수의 차이가 유의미하였다 $\left(\mathrm{F}_{(2,83)}=3.432, p=0.037\right)$.

집단과 단어 조건에 따른 정반응 점수를 확인한 결과(Table 2, Figure 2) 집단과 단어 조건의 상호작용 효과는 없었으나 $\left(\mathrm{F}_{(4,166)}=\right.$ $1.382, p=0.243$ ), 집단에 따른 정반응 점수는 $\mathrm{SMC}>\mathrm{aMCI}>$ $\mathrm{AD}$ 순으로 낮아지는 양상을 보여 유의미한 차이가 나타났으며

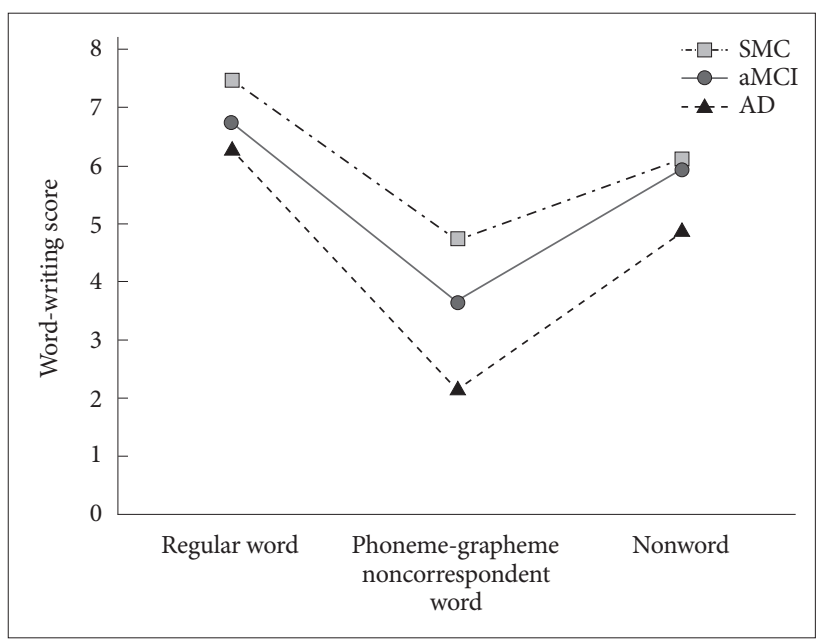

Figure 2. Writing scores according to the word types. SMC: subjective memory complaint, aMCl: amnestic mild cognitive impairment, AD: Alzheimer's disease.

Table 2. Writing scores according to the word types

\begin{tabular}{lrrr}
\hline \multicolumn{1}{c}{ Word type } & SMC $(\mathrm{n}=30)$ & $\mathrm{aMCI}(\mathrm{n}=30)$ & $\mathrm{AD}(\mathrm{n}=27)$ \\
\hline Regular word & $7.47(0.819)$ & $6.73(1.388)$ & $6.33(1.468)$ \\
Irregular word & $4.73(2.612)$ & $3.63(1.921)$ & $2.19(1.545)$ \\
Nonword & $6.13(1.525)$ & $5.90(1.845)$ & $4.89(1.761)$ \\
Total & $18.33(4.310)$ & $16.30(4.458)$ & $13.41(3.331)$ \\
\hline
\end{tabular}

Values are presented as mean (SD). SMC: subjective memory complaint, aMCI: amnestic mild cognitive impairment, AD: Alzheimer's disease
$\left(\mathrm{F}_{(2,83)}=3.432, p=0.037\right)$, 집단 내 단어 조건에 따른 정반응 수 는 규칙 단어 > 비단어 > 불규칙 단어 순으로 낮아지는 양상 을 보여 유의미한 차이가 나타났다 $\left(\mathrm{F}_{(2,83)}=4.133, p=0.018\right)$.

각 단어 조건에서 집단 간의 차이에 대한 사후분석을 실시한 결과, 규칙 단어 $\left(\mathrm{F}_{(2,86)}=6.080, p=0.003\right)$, 불규칙 단어 $\left(\mathrm{F}_{(2,86)}=\right.$ $10.588, p<0.001)$, 비단어 $\left(\mathrm{F}_{(2,87)}=4.169, p=0.019\right)$ 모두 집단 간 유의미한 차이가 나타났다. 규칙 단어에서 $\mathrm{SMC}$ 와 $\mathrm{aMCI}(p=$ $0.065), \mathrm{aMCI}$ 와 $\mathrm{AD}(p=0.453)$ 는 차이가 없었으나, $\mathrm{SMC}$ 와 $\mathrm{AD}(p=0.003)$ 는 유의미한 차이가 나타났다. 불규칙 단어에서 는 $\mathrm{SMC}$ 와 $\mathrm{aMCI}(p=0.109)$ 는 차이가 없었으나, $\mathrm{SMC}$ 와 $\mathrm{AD}$ $(p<0.001), \mathrm{aMCI}$ 와 $\mathrm{AD}(p=0.028)$ 는 유의미한 차이가 나타 났다. 비단어에서는 $\mathrm{SMC}$ 와 $\mathrm{aMCI}(p=0.858), \mathrm{aMCI}$ 와 $\mathrm{AD}$ ( $p=$ $0.073)$ 는 차이가 없었으나, $\mathrm{SMC}$ 와 $\mathrm{AD}(p=0.020)$ 는 유의미한 차이가 나타났다.

각 집단 내에서 사후분석을 실시한 결과, 모든 집단 내에서 단어 조건 간의 차이가 유의미하였다. $\mathrm{SMC}$ 에서 규칙 단어와 불 규칙 단어 $\left(t_{(29)}=6.675, p<0.001\right)$, 규칙 단어와 비단어 $\left(t_{(29)}=\right.$ $5.224, p<0.001)$, 불규칙 단어와 비단어 $\left(t_{(29)}=-3.881, p=0.001\right)$ 에서 차이가 나타났다. $\mathrm{aMCl}$ 에서도 규칙 단어와 불규칙 단어 $\left.\left(t_{29}\right)=10.579, p<0.001\right)$, 규칙 단어와 비단어 $\left(t_{(29)}=3.470, p=\right.$ $0.002)$, 불규칙 단어와 비단어 $\left(t_{(29)}=-7.481, p<0.001\right)$ 에서 차이 가 나타났다. $\mathrm{AD}$ 에서도 규칙 단어와 불규칙 단어( $t_{(26)}=11.893$, $p<0.001)$, 규칙 단어와 비단어 $\left(t_{(26)}=4.914, p<0.001\right)$, 불규칙 단어와 비단어 $\left(t_{(26)}=-5.635, p<0.001\right)$ 에서 차이가 나타났다.

\section{집단 간 오류 및 오류 유형 비교}

자소 수준에서의 오류 유형을 살펴보기 위하여 집단과 오류 유형에 따른 자소 오류 개수의 차이를 확인한 결과(Table 3), 집 단과 단어 조건에 따른 상호작용 효과는 없었으며 $\left(\mathrm{F}_{(2,83)}=2.717\right.$, $p=0.067)$, 집단 간 차이도 없었으나 $\left(\mathrm{F}_{(2,83)}=3.011, p=0.055\right)$, 집단 내 단어 조건에 따른 자소 오류 개수는 유의미한 차이가 나타났다 $\left(\mathrm{F}_{(2,83)}=6.785, p=0.009\right)$.

각 집단 내에서 단어 조건에 따른 차이가 유의미한지 사후분 석을 실시한 결과, $\mathrm{SMC}$ 는 대치가 가장 많았으며, 생략과 첨가

Table 3. The number of erroneous responses according to error types

\begin{tabular}{lccc}
\hline Error type & $\mathrm{SMC}(\mathrm{n}=30)$ & $\mathrm{aMCI}(\mathrm{n}=30)$ & $\mathrm{AD}(\mathrm{n}=27)$ \\
\hline Elision & $0.40(0.621)$ & $0.60(0.932)$ & $1.11(1.219)$ \\
Substitution & $5.57(4.508)$ & $8.00(5.356)$ & $11.19(4.985)$ \\
Addition & $0.40(0.563)$ & $0.60(0.855)$ & $0.96(0.587)$ \\
Others & 0 & $0.03(0.183)$ & 0 \\
NR & 0 & 0 & $0.11(0.577)$ \\
\hline
\end{tabular}

Values are presented as mean (SD). SMC: subjective memory complaint, aMCI: amnestic mild cognitive impairment, AD: Alzheimer's disease, NR: no response 
순으로 오류가 나타났다. 생략과 첨가 $\left(t_{(29)}=0.000, p=1.000\right)$ 는 차이가 없었으나, 생략과 대치 $\left.\left(t_{29}\right)=-6.912, p<0.001\right)$, 생략과 기타 $\left(t_{(29)}=-3.525, p=0.001\right)$, 생략과 무반응 $\left(t_{(29)}=-3.525, p=\right.$ $0.001)$, 대치와 첨가 $\left(t_{(29)}=6.682, p<0.001\right)$, 대치와 기타 $\left(t_{(29)}=\right.$ $6.763, p<0.001)$, 대치와 무반응 $\left(t_{(29)}=6.763, p<0.001\right)$, 첨가 와 기타 $\left(t_{(29)}=3.890, p=0.001\right)$, 첨가와 무반응 $\left(t_{(29)}=3.890, p=\right.$ 0.001)은 유의미한 차이가 나타났다.

$\mathrm{aMCI}$ 는 대치가 가장 많았으며, 생략, 첨가, 기타 순으로 오류 가 나타났다. 생략과 첨가 $\left(t_{(29)}=0.000, p=1.000\right)$, 기타와 무반 응 $\left(t_{(29)}=1.000, p=0.326\right)$ 은 차이가 없었으나, 생략과 대치 $\left(t_{(29)}=\right.$ $-8.743, p<0.001)$, 생략과 기타 $\left(t_{(29)}=3.798, p=0.001\right)$, 생략과 무반응 $\left(t_{(29)}=3.525, p=0.001\right)$, 대치와 첨가 $\left(t_{(29)}=8.450, p<\right.$ $0.001)$, 대치와 기타 $\left(t_{29}=8.303, p<0.001\right)$, 대치와 무반응 $\left(t_{229}=\right.$ $8.181, p<0.001)$, 첨가와 기타 $\left(t_{(29)}=4.264, p<0.001\right)$, 첨가와 무반응 $\left(t_{(29)}=3.844, p=0.001\right)$ 은 유의미한 차이가 나타났다.

$\mathrm{AD}$ 또한 대치가 가장 많았으며, 생략, 첨가, 무반응 순으로 오류가 나타났다. 생략과 첨가 $\left.\left(t_{26}\right)=0.642, p=0.527\right)$, 기타와 무 반응 $\left(t_{(26)}=-1.000, p=0.327\right)$ 은 차이가 없었으나, 생략과 대치 $\left(t_{(26)}=-12.210, p<0.001\right)$, 생략과 기타 $\left(t_{(26)}=4.734, p<0.001\right)$, 생략과 무반응 $\left(t_{(26)}=4.416, p<0.001\right)$, 대치와 첨가 $\left(t_{266}=11.182\right.$, $p<0.001)$, 대치와 기타 $\left(t_{(26)}=11.659, p<0.001\right)$, 대치와 무반 응 $\left(t_{(26)}=11.354, p<0.001\right)$, 첨가와 기타 $\left(t_{(26)}=8.522, p<\right.$ $0.001)$, 첨가와 무반응 $\left(t_{(26)}=5.410, p<0.001\right)$ 은 유의미한 차이 가 나타났다.

단어 수준에서 오류 유형을 살펴보기 위하여 불규칙 단어에 서 PPE 오류와 PIE 오류를 확인한 결과(Table 4), 집단과 단어 조건에 따른 상호작용 효과는 없었으며 $\left(\mathrm{F}_{(2,83)}=1.088, p=\right.$ $0.342)$, 집단 간 차이도 없었고 $\left(\mathrm{F}_{(2,83)}=2.986, p=0.056\right)$, 집단 내 $\mathrm{PPE}$ 오류와 PIE 오류의 차이도 없었다 $\left(\mathrm{F}_{(2,83)}=0.312, p=0.649\right)$.

단어 수준에서 오류 유형을 살펴보기 위하여 비단어에서의 어 휘화 오류와 목표가 아닌 비단어 오류를 확인한 결과(Table 5), 집단과 오류 유형에 따른 상호작용 효과는 유의미하게 나타났으 나 $\left(\mathrm{F}_{(2,83)}=3.145, p=0.048\right)$, 집단 간 차이는 없었으며 $\left(\mathrm{F}_{(2,83)}=\right.$ $0.641, p=0.529$ ), 집단 내 어휘화 오류와 목표가 아닌 비단어 오류 간의 차이도 없었다 $\left(\mathrm{F}_{(2,83)}=3.318, p=0.072\right)$.

Table 4. Descriptive statistics of error type in irregular word-writing task

\begin{tabular}{cccc}
\hline Error type & SMC $(\mathrm{n}=30)$ & aMCI $(\mathrm{n}=30)$ & $\mathrm{AD}(\mathrm{n}=27)$ \\
\hline PPE & $1.80(1.648)$ & $2.10(1.125)$ & $3.15(1.379)$ \\
PIE & $1.57(1.251)$ & $2.27(1.461)$ & $2.67(1.144)$ \\
\hline
\end{tabular}

Values are presented as mean (SD). SMC: subjective memory complaint, aMCI: amnestic mild cognitive impairment, AD: Alzheimer's disease, PPE: phonologically plausible error, PIE: phonologically implausible error

\section{집단 간 단어의 쓰기 시간 및 쉼 시간 비교}

집단과 자소 위치에 따른 '1음절 단어 쓰기 시간'(G1, G2, $\mathrm{G} 3$ )을 확인한 결과(Table 6), 집단과 자소 위치의 상호작용 효 과는 없었으며 $\left(\mathrm{F}_{(4,166)}=0.181, p=0.932\right)$, 집단에 따른 차이도 없었고 $\left(\mathrm{F}_{(2,83)}=0.456, p=0.636\right)$, 집단 내 자소 위치에 따른 차 이도 없었다 $\left(\mathrm{F}_{(2,83)}=0.897, p=0.399\right)$.

집단과 쉼 위치에 따른 ' 1 음절 단어 쓰기 쉼 시간'(P1, P2) 을 확인한 결과(Table 7), 집단과 쉼 위치의 상호작용 효과는 없었으며 $\left(\mathrm{F}_{(1,83)}=0.279, p=0.757\right)$, 집단에 따른 차이도 없었고 $\left(\mathrm{F}_{(2,83)}=0.701, p=0.499\right)$, 집단 내 쉼 위치에 따른 차이도 없었 다 $\left(\mathrm{F}_{(1,83)}=0.332, p=0.566\right)$.

\section{DISCUSSIONS}

본 연구는 세 집단(SMC, $\mathrm{aMCI}, \mathrm{AD})$ 의 단어 조건(규칙 단어, 불규칙 단어, 비단어)별 정반응 수와 오류 유형을 살펴보고, 한 글의 시공간적인 특성에 따라 초성, 중성, 종성으로 이루어진 1 음절 단어의 쓰기 시간 및 쉼 시간을 살펴봄으로써 인지기능 변화에 따른 한글 쓰기 특성을 다각적으로 확인하고자 하였다.

Table 5. Descriptive statistics of error type in nonword-writing task

\begin{tabular}{lccc}
\hline \multicolumn{1}{c}{ Error type } & SMC $(\mathrm{n}=30)$ & $\mathrm{aMCI}(\mathrm{n}=30)$ & $\mathrm{AD}(\mathrm{n}=27)$ \\
\hline Lexicalization & $0.70(0.837)$ & $0.73(0.740)$ & $1.63(1.079)$ \\
Non-target nonword & $1.17(1.289)$ & $1.37(1.650)$ & $1.48(1.341)$ \\
\hline
\end{tabular}

Values are presented as mean (SD). SMC: subjective memory complaint, aMCI: amnestic mild cognitive impairment, AD: Alzheimer's disease

Table 6. Descriptive statistics of writing time in one-syllable wordwriting tasks (ms)

\begin{tabular}{cccc}
\hline $\begin{array}{c}\text { Writing } \\
\text { time }\end{array}$ & SMC $(\mathrm{n}=30)$ & $\mathrm{aMCI}(\mathrm{n}=30)$ & $\mathrm{AD}(\mathrm{n}=27)$ \\
\hline $\mathrm{G} 1$ & $556.436(184.197)$ & $550.879(164.412)$ & $636.937(309.724)$ \\
G2 & $579.047(205.509)$ & $562.914(173.430)$ & $694.783(421.021)$ \\
G3 & $558.458(211.522)$ & $527.227(146.821)$ & $598.853(325.729)$ \\
\hline
\end{tabular}

Values are presented as mean (SD). SMC: subjective memory complaint, aMCI: amnestic mild cognitive impairment, AD: Alzheimer's disease, G1: initial consonant, G2: medial vowel, G3: final consonant

Table 7. Descriptive statistics of pause time in one-syllable wordwriting tasks (ms)

\begin{tabular}{cccc}
\hline $\begin{array}{c}\text { Pause } \\
\text { time }\end{array}$ & SMC $(\mathrm{n}=30)$ & aMCI $(\mathrm{n}=30)$ & $\mathrm{AD}(\mathrm{n}=27)$ \\
\hline P1 & $214.160(185.350)$ & $252.867(260.906)$ & $244.110(148.350)$ \\
P2 & $227.870(107.118)$ & $367.258(295.948)$ & $456.097(1146.092)$ \\
\hline
\end{tabular}

Values are presented as mean (SD). SMC: subjective memory complaint, aMCI: amnestic mild cognitive impairment, AD: Alzheimer's disease, P1: between initial consonant and medial vowel, P2: between medial vowel and final consonant 
첫 번째로, 세 집단의 총 정반응 점수에서 $\mathrm{SMC}$ 와 $\mathrm{aMCI}$ 집 단은 차이가 없었으나 $\mathrm{AD}$ 집단은 $\mathrm{SMC}$ 와 $\mathrm{aMCI}$ 집단에 비하 여 정반응 점수가 낮은 것으로 나타났다. 이는 $\mathrm{AD}$ 에서 인지기 능 장애와 더불어 철자 쓰기와 관련된 측두-두정엽(temporoparietal lobe)의 손상이 나타나기 때문으로 생각된다. 집단과 단어 조건에 따른 정반응 점수를 확인하였을 때, $\mathrm{SMC}$ 와 $\mathrm{aMCI}$ 의 경우 모든 단어 조건에서 수행력의 차이가 없었다. 이러한 결과는 $\mathrm{aMCI}$ 의 경우 비록 인지기능장애가 있다고 하더라도 쓰 기 수행에 필요한 어휘통로나 음운통로를 활용하는 능력이 인 지기능장애가 없는 $\mathrm{SMC}$ 수준으로 유지되고 있음을 의미한다. 그러나 $\mathrm{aMCI}$ 와 $\mathrm{AD}$ 집단의 경우 규칙 및 비단어 쓰기에서는 집단 간 수행력의 차이가 없었던 것과는 대조적으로 불규칙 단 어에서는 $\mathrm{aMCI}$ 에 비해 $\mathrm{AD}$ 집단의 수행력이 유의하게 저하되 는 것으로 나타났다. 이러한 결과는 $\mathrm{AD}$ 질환의 중증도에 따른 쓰기 처리 과정의 감퇴 양상과 연관지어 생각해 볼 수 있다. 자 소와 음소가 일치하지 않는 불규칙 단어를 쓰기 위한 어휘 통 로는 실비안열(sylvian fissure)을 제외한 측두-두정엽의 각이 랑(angular gyrus)이나 방추이랑(fusiform gyrus)과 주로 관련 이 있는데, 이는 $\mathrm{AD}$ 의 주요 병소이며 질환의 초기부터 침범되 는 것으로 보고된다(Tompkins, 2002). 또한 본 연구에 참여한 $\mathrm{AD}$ 환자의 중증도가 모두 경도(CDR1)에 해당하였으므로 이 단계에서는 음운 통로의 기능이 유지되기 때문에 음소와 자소 가 대응되는 규칙 단어나 비단어 쓰기에서 $\mathrm{aMCI}$ 와 차이가 나 지 않은 것으로 생각된다.

각 집단 내에서 단어 조건에 따른 차이를 확인하였을 때는 모든 집단에서 규칙 단어, 비단어, 불규칙 단어 순으로 정반응 점수가 낮은 것으로 나타났다. 이러한 결과는 먼저 단어 조건이 가진 난이도에 기인한 것으로 해석해 볼 수 있다. 단어 쓰기의 처리 과정은 단어의 어휘성(lexicality)에 따라 어휘 통로를, 철 자규칙성(regularity)에 따라 음운 통로를 선택하여 수행하게 된다. 내부철자사전에 저장되어 있는 규칙 단어의 경우 어휘 통 로를 통해 단어 전체의 철자를 한꺼번에 출력하여 쓰기를 수행 할 수 있어서 보다 자동화된 난이도가 쉬운 과제인 반면에 비 단어는 음소에 대응하는 자소를 일일이 찾아 철자당 음소-자 소 변환(phoneme to grapheme conversion) 단계를 거쳐 쓰기 를 수행해야 하므로 규칙 단어에 비해 쓰기 처리 과정에서의 효율성이 저하된다( $\mathrm{Na}, 2016)$. 불규칙 단어의 경우에는 철자규 칙성 측면에서 음운변동이 적용되어야 하기 때문에 자소와 음 소가 일치하지 않아 음운 통로를 사용할 수 없고, 반드시 내부 철자사전에 저장되어 있는 단어를 찾는 어휘 통로만을 활용해 야 한다. 특히 제시된 음소들을 듣고, 음운변동에 따라 자소를 선택하거나 억제(inhibition)하는 과정이 필요하기 때문에 규칙 단어나 비단어와 비교하여 인지적 처리 과정이 더욱 요구된다
(Yoon \& Lee, 2014). 따라서 이러한 단어 조건이 가진 난이도 특성으로 인하여 모든 집단에서 규칙 단어, 비단어, 불규칙 단 어 순으로 점수가 낮아진 것으로 해석된다.

다음으로 단어 조건에 있어 집단 간 동일한 수행력 양상을 보인 이유를 인지기능 감퇴의 연속선상에서 살펴보았다. $\mathrm{AD}$ 집단은 이미 언급한 것처럼 초기 $\mathrm{AD}$ 의 대표적인 임상 특징인 어휘-의미 능력의 저하와 음운 통로의 보전에 근거하여 음운 통로를 활용해서 쓸 수 있는 규칙단어나 비단어의 수행력에 비 하여 어휘 통로를 활용해야 하는 불규칙 단어의 쓰기를 가장 어려워하였을 것으로 생각된다. $\mathrm{aMCI}$ 의 경우에도 대면이름대 기 과제를 통해 어휘-의미 수행력이 저하된다는 연구 결과들 (Petersen et al., 1999; Won et al., 2017)이 보고되고 있으며, 최근에는 신경심리검사에서 정상 수준의 인지기능을 유지하고 있지만 기억력 저하를 주관적으로 호소하는 SMC 또한 이름대 기 등의 과제를 통하여 어휘-의미 능력이 저하되는 등(Markova, 2017) 언어적인 측면에서의 경미한 수행력 저하가 보고되 고 있다. 따라서 인지기능 감퇴 정도에 따라 단어 조건에 따른 유사한 수행양상을 보인 본 연구의 결과는 매년 $\mathrm{AD}$ 로 10 15\% 이환되는 $\mathrm{aMCI}$ 뿐만 아니라, $\mathrm{SMC}$ 환자에서도 증상 호소 4 8년 후 $25 \%$ 정도가 $\mathrm{aMCI}$ 로 이환되거나 인지저하를 호소하지 않는 사람들에 비하여 $10.9 \%$ 가 $\mathrm{AD}$ 로 이환되는 것이 밝혀진 연구 (Mitchell et al., 2014; Petersen et al., 1999)에서와 같이 SMC 의 쓰기 수행력 또한 $\mathrm{AD}$ 를 예측하는 중요한 변수가 될 수 있 으며, $\mathrm{SMC}$ 와 $\mathrm{aMCI}$ 는 $\mathrm{AD}$ 연속선상에 있는 전임상적 단계라는 선행연구(Mitchell et al., 2014; Petersen et al., 1999)를 지지하 는 근거가 될 수 있다.

두 번째로, 세 집단의 전체 단어에 대한 오류 유형을 확인하 였을 때, 먼저 자소 수준에서의 오류에서 집단 간의 차이 없이 모든 집단에서 대치가 가장 많았으며, 생략과 첨가 순으로 오 류가 나타났다. 대치 오류가 가장 많았던 결과는 한글을 사용 하는 정상 노년층을 대상으로 한 연구(Yoon \& Lee, 2014)나 조기발현 $\mathrm{AD}$ (early onset Alzheimer's disease, $\mathrm{EOAD}$ ) 환자 를 대상으로 한 연구의 결과(Yoon et al., 2011)와도 동일한데, 한글은 시각적 형태 내에 각 자소가 공간적으로 배치되는 특성 을 가지기 때문에 목표 자소를 모를 경우 자소를 생략하여 그 공간을 비워두는 것보다는 알고 있는 다른 자소를 채워 넣는 선택을 하기 때문인 것으로 생각해 볼 수 있다. 또한 다른 집단 과 달리 $\mathrm{AD}$ 에서는 무반응 오류도 관찰되었는데, 각 자소를 대 치하거나 생략, 첨가하는 등의 시도를 하지 않고 단어 전체를 쓰지 않는 양상을 보인 것이다. $\mathrm{AD}$ 환자의 치매 중증도에 따른 구두 이름대기 능력을 확인한 연구(Kim et al., 1997)에서는 정 상 성인과 $\mathrm{CDR}$ 0.5에 해당하는 $\mathrm{AD}$ 환자는 무반응 오류가 없 었으나, $\mathrm{CDR} 1$ 에서부터 무반응 오류가 관찰되었다. 본 연구에 
참여한 $\mathrm{SMC}$ 와 $\mathrm{MCI}$ 집단에서는 무반응 오류가 나타나지 않았 지만, $\mathrm{CDR} 1$ 에서부터 무반응 오류가 나타나 쓰기 산출에서도 구어 산출과 유사한 양상이 관찰됨을 확인하였다.

추가적으로 불규칙 단어에서 두드러질 수 있는 오류를 확인 하기 위하여 PPE 오류와 PIE 오류를 측정한 결과, 집단 간 차 이, 각 집단 내에서 오류 유형의 차이, 집단과 오류 유형에 따른 상호작용 효과는 나타나지 않았다. PPE 오류는 해당 단어를 듣고 소리 나는 대로 자소를 산출하는 양상이므로 이는 음운 통로가 건재함을 보여주는 근거가 되며, PIE 오류는 소리 나는 대로도 산출하지 못하는 양상으로 음운 통로의 손상을 의미한 다. 따라서 치매의 후기로 갈수록 PIE의 비율이 매우 높아지는 데(Yoon et al., 2009), 본 연구에 참여한 $\mathrm{AD}$ 는 비교적 경한 중 증도의 환자들이었으므로 PIE 오류가 크게 증가하는 양상은 나타나지 않은 것으로 보인다. 비단어에서 두드러지는 오류를 확인하기 위하여 어휘화 오류와 목표가 아닌 비단어 오류를 측 정한 결과에서, 집단 간 차이와 각 집단 내에서 오류 유형의 차 이는 나타나지 않았으나, 집단과 오류 유형에 따른 상호작용 효 과는 유의하였다. 이렇게 상호작용이 관찰된 결과는 $\mathrm{SMC}$ 와 $\mathrm{aMCI}$ 에서는 어휘화 오류보다 목표가 아닌 비단어 오류가 더 많았던 반면에, $\mathrm{AD}$ 에서는 반대 양상을 보인 것에 기인한 것으 로 생각된다. 또한 $\mathrm{AD}$ 집단은 정반응 점수가 낮고, 다른 집단 에서 보이지 않았던 무반응 오류를 보였기 때문에 통계적으로 유의하지는 않지만 $\mathrm{SMC}$ 및 $\mathrm{aMCI}$ 와는 다소 다른 양상을 보인 것으로 보인다.

세 번째로, 세 집단의 1 음절 단어 쓰기 과제에서 자소 위치 (G1, G2, G3)에 따른 쓰기 시간을 확인하였을 때, 집단 간 차 이, 집단 내 자소 위치에 따른 차이, 집단과 자소 위치의 상호작 용 효과는 모두 나타나지 않았다. 자소 쓰기 시간은 각 자소별 로 처음 펜이 닿은 시간부터 펜을 뗀 시간까지 측정하기 때문 에 철자단계를 통해 이미 인출된 목표 철자를 손의 움직임을 통해 집행하는 시간을 의미한다. 본 연구에 포함된 대상자들은 모두 주요한 운동학적 문제가 없었으며 $\mathrm{AD}$ 나 $\mathrm{MCI}$ 의 경우 질 환의 초기에 운동적인 측면에서는 퇴화가 나타나지 않는다는 연구 결과(Pettersson et al., 2005)에 따라 운동학적 문제가 두 드러지지 않는 대상자 집단 간에 차이가 나타나지 않았을 가능 성이 있다.

쉼 시간 또한 집단 간 차이, 집단 내 쉼 위치 $(\mathrm{P} 1, \mathrm{P} 2)$ 에 따른 차이, 집단과 심 위치의 상호작용 효과 모두 나타나지 않았다. 쉼 시간의 경우는 자소 시간과는 다르게 한 자소를 쓰고 난 후 다음 자소를 쓰기 직전까지 펜이 닿지 않는 자소 사이의 시간 을 측정하는 것으로, 적절한 자소를 찾고, 자소의 위치 및 배열 등의 계획을 처리하는 시간이 반영된다(Rosenblum, 2013). 특 히 한글은 초성, 중성, 종성 자소들로 한 음절의 글자가 구성되
며, 음절이 쓰이는 방향은 중성에 해당하는 모음의 위치에 따 라 결정되므로 쓰기 수행 시 다른 문자에 비하여 시공간적 처 리 과정이 더욱 중요한 가치를 가진다(Yoon et al., 2011). 이러 한 시공간적 특수성을 반영하여 $\mathrm{AD}$ 환자에게 초성, 중성, 종 성으로 이루어진 1음절 한글 단어를 듣고 받아 쓰는 과제를 실 시하여 초성과 중성 사이의 심(P1), 중성과 종성 사이의 심(P2) 시간을 측정하여 비교한 연구(Yoon et al., 2018)에서는 $\mathrm{AD}$ 환 자가 정상인에 비하여 모든 쓰기 시간 및 심 시간에서 느린 수 행력을 보였으며, 특히 P2에 비하여 P1의 심 시간이 더 느린 것 으로 나타났다. 한글 쓰기 과정에서 초성은 항상 음절의 상단 에 위치하고, 종성은 항상 음절의 하단에 위치하지만 중성의 경우에는 자소 내에 배열되는 모음의 위치에 따라 음절의 종단 방향, 횡단방향, 종횡단 혼합방향을 결정하는 특성을 지닌다.

이에 본 연구의 결과 또한 인지기능의 저하에 따라 $\mathrm{P} 1$ 이 유 의하게 지연될 것으로 기대하였으나 선행연구의 결과와는 차이 가 있었다. 이는 각 연구에 포함된 대상자나 과제의 차이에 기 인할 수 있다. 먼저, 선행연구에서는 $\mathrm{AD}$ 환자군이 질환의 초기 부터 시공간능력 저하가 두드러지는 $\mathrm{EOAD}$ 로 구성되었던 것 과 비교하여 본 연구에 포함된 $\mathrm{AD}$ 환자의 경우 모두 LOAD에 속하며, 이들은 $\mathrm{EOAD}$ 에 비하여 초기 단계에서 시공간 기능의 손상이 심하게 두드러지지 않는 것으로 알려져 있다(Joubert et al., 2016). 따라서 중성 쓰기는 초성이나 종성에 비하여 시공간 적인 능력을 더 요구하므로 시공간 기능을 담당하는 두정엽 (parietal lobe)의 손상이 두드러지는 선행연구의 $\mathrm{EOAD}$ 집단 에서 이를 위한 처리 과정에 더 어려움을 보인 것으로 해석할 수 있겠다. 또한 선행연구(Yoon et al., 2018)의 과제는 모든 단 어가 자소와 음소가 대응하는 1음절의 규칙 단어로만 구성되 었으나 본 연구에는 1음절 불규칙 단어 또한 포함되어 있었는 데, 불규칙 단어의 경우 세 집단 모두 다른 단어 조건에 비하여 오류율이 가장 높았으며 $\mathrm{SMC}$ 에서 $\mathrm{AD}$ 로 갈수록 정반응 수행 력이 저하되었다. 본 연구에서는 심 시간 측정 시 각 자소가 정 반응을 보인 경우에만 다음 자소를 계획하는 시간으로 간주하 여 그 시간을 측정한다. 따라서 $\mathrm{SMC}$ 의 경우 불규칙 단어와 같 이 어려운 조건에서 자소를 바르게 산출하기 위하여 더 많은 시간을 고민하였을 가능성이 있고, 대조적으로 $\mathrm{AD}$ 에서는 오 반응 비율이 높고 다른 집단에서는 관찰되지 않았던 모른다고 포기하는 오반응 양상들도 관찰되어, 정확히 답을 알고 있는 경 우에만 쓰기를 수행하였을 가능성이 있겠다.

결론적으로 $\mathrm{SMC}, \mathrm{aMCI}, \mathrm{AD}$ 는 인지기능 감퇴 정도에 따라 집단 간 쓰기 수행력의 차이가 나타나지만, 특히 불규칙 단어 에서 다른 두 집단에 비하여 $\mathrm{AD}$ 집단의 수행력 저하가 두드러 지게 나타나 인지기능 저하에 따른 어휘 통로의 감퇴를 확인하 였다. 그리고 모든 집단에서 규칙 단어, 비단어, 불규칙 단어 순 
으로 수행력이 저하되었으며 대치, 생략, 첨가 순으로 오류를 보 여 집단별로 유사한 수행 양상이 관찰되었다. 본 연구는 $\mathrm{AD}$ 는 질환의 초기 단계부터 나타나는 철자 처리 과정에서의 쓰기 수 행력 저하를 재확인하였을 뿐만 아니라 $\mathrm{AD}$ 의 임상 전단계에 해당하는 $\mathrm{SMC}$ 와 $\mathrm{aMCI}$ 집단의 단어 조건별 쓰기 수행력을 탐 색하고 그 양상에 있어 $\mathrm{AD}$ 와의 유사성을 관찰함으로써, 신경 병리적 손상으로 인한 $\mathrm{AD}$ 로의 진행 과정을 언어적인 측면에서 쓰기라는 복합적 인지 활동을 통하여 확인한 최초의 연구라는 점에서 의의가 있다. 본 연구의 제한점은 다음과 같다. 쓰기에 대한 시공간 및 운동적 측면에서 글자 크기나 손의 단순 운동 속도 등은 쓰기 속도에 영향을 줄 수 있다. 이러한 맥락에서 운 동학적 문제가 두드러지는 파킨슨병 환자를 대상으로 쓰기 속 도를 살펴본 연구(Lee et al., 2020)에서는 실제 쓰기 시간을 정 확히 측정 및 반영하기 위하여 글자 크기를 통제할 필요성을 역설하였고, 획의 길이를 획을 쓰는 데 걸린 소요시간으로 나 눈 속력(speed)으로 분석하는 것이 타당하다고 주장하였다. 이 에 추후 연구에서는 글자 크기를 통제한 상태에서 속력을 산정 하여 쓰기 속도(writing speed)를 측정할 필요가 있다. 또한 $\mathrm{SNSB}$ 와 같은 종합 인지기능검사에서 객관적인 인지장애가 없 는 것으로 판단되면서 인지 감퇴를 전혀 호소하지 않는 완전한 정상 노년층을 대상으로 쓰기 능력을 확인하여 주관적 인지감 퇴 호소 여부에 따른 쓰기 능력 차이를 확인하는 것도 필요하 겠다.

중심 단어 : 알츠하이머병·경도인지장애·주관적 기억 호소·쓰 기 통로.

\section{Ethical Statement}

The study was approved by the Institutional Review Board of Samsung Medical Center (IRB-2018-06-140-001). Written informed consent was obtained from all participants.

\section{Acknowledgments} N/A

\section{Declaration of Conflicting Interests \\ There are no conflict of interests.}

\section{Funding}

This research was supported by Hallym University Research Fund in 2020 (No. HRF-202006-004). This material is based upon work supported by the Ministry of Trade, Industry \& Energy (MOTIE, Korea) under Industrial Technology Innovation Program (10063384).

\section{Author Contributions}

Conceptualization: Eun Byeol Cho, Duk L. Na, Ji Hye Yoon. Data curation: Eun Byeol Cho. Formal analysis: Han Sol Lee, Eun Byeol Cho. Funding acquisition: Duk L. Na, Ji Hye Yoon. Investigation: Han Sol Lee. Methodology: Han Sol Lee, Eun Byeol Cho. Software: Duk L. Na, Ji Hye Yoon. Supervision: Duk L. Na, Ji Hye Yoon. Visualization: Han Sol Lee. Writing_original draft: Han Sol Lee. Writing_review \& editing: Ji Hye
Yoon. Approval of final manuscript: all authors.

\section{ORCID iDs}

Han Sol Lee https://orcid.org/0000-0002-6290-2566

Ji Hye Yoon https://orcid.org/0000-0003-1403-2276

\section{REFERENCES}

Barnes, L. L., Schneider, J. A., Boyle, P. A., Bienias, J. L., \& Bennett, D. A. (2006). Memory complaints are related to Alzheimer disease pathology in older persons. Neurology, 67(9), 1581-1585.

Choi, H. W. (2004). Investigation on the Pronunciation of Standard Language 3. Seoul: National Institute of Korean Language.

Christensen, K. J., Multhaup, K. S., Nordstrom, S., \& Voss, K. (1991). A cognitive battery for dementia: Development and measurement characteristics. Psychological Assessment: A Journal of Consulting and Clinical Psychology, 3(2), 168-174.

Dubois, B., Feldman, H. H., Jacova, C., Dekosky, S. T., Barberger-Gateau, P., Cummings, J., et al. (2007). Research criteria for the diagnosis of Alzheimer's disease: revising the NINCDS-ADRDA criteria. The Lancet. Neurology, 6(8), 734-746.

Huff, F. J., Corkin, S., \& Growdon, J. H. (1986). Semantic impairment and anomia in Alzheimer's disease. Brain and Language, 28(2), 235-249.

Jo, H. Y. (2000). Korean Vocabulary Education. Seoul: Pagijong Press.

Joubert, S., Gour, N., Guedj, E., Didic, M., Guériot, C., Koric, L., et al. (2016). Early-onset and late-onset Alzheimer's disease are associated with distinct patterns of memory impairment. Cortex, 74, 217-232.

Kang, M. A. \& Baek, Y. M. (2014). The neurocognitive function between the patients who had subjective memory impairment and mild cognitive impairment. Journal of the Korean Geriatrics Society, 18(1), 7-15.

Kang, Y., Jahng, S., \& Na, D. L. (2012). Seoul Neuropsychological Screening Battery (SNSB-II). Incheon: Human Brain Research \& Consulting Co.

Kang, Y. W. \& Na, D. L. (2003). Seoul Verbal Learning Test. (2nd ed.). Seoul: Human Brain Research and Consulting Co.

Kawa, J., Bednorz, A., Stępień, P., Derejczyk, J., \& Bugdol, M. (2017). Spatial and dynamical handwriting analysis in mild cognitive impairment. Computers in Biology and Medicine, 82, 21-28.

Kee, B. S. (1996). A preliminary study for the standardization of geriatric depression scale short form-Korea version. Journal of Korean Neuropsychiatric Association, 35(2), 298-306.

Kim, H. (2012). Neurologic Speech-Language Disorders. (1st ed.), (pp.190204). Seoul: SigmaPress.

Kim, H., Kim, E. Y., \& Na, D. L. (1997). Naming deficits in patients with dementia of the Alzheimer type: Error analysis of Korean version-Boston Naming Test. Journal of the Korean Neurological Association, 15(5), 1012-1021.

Kim, H. S. (2005). Research on the Frequency of Use in Modern Languages. (2nd ed.). Seoul: National Institute of Korean Language.

Kim, Y. R., \& Jung, H. Y. (2007). Depression and cognitive impairment in the elderly. Journal of Korean Geriatric Psychiatry, 11(1), 20-24.

Ku, H. M., Kim, J. H., Kwon, E. J., Kim, S. H., Lee, H. S., Ko, H. J., et al. (2004). A Study on the Reliability and Validity of Seoul-Instrumental Activities of Daily Living (S-IADL). Journal of Korean Neuropsychiatric Association, 43(2), 189-199.

Lee, H. S., Youn, J. Cho, J. W., Ahn, J. H., Yoon, J. H., \& Na, D. L. (2020). Characteristics of writing in Parkinson's disease: Focused on pen pressure, letter size, and writing speed. Communication Sciences and Disorders, 25(1), 63-74.

Markova, H., Andel, R., Stepankova, H., Kopecek, M., Nikolai, T., Hort, J., et al. (2017). Subjective cognitive complaints in cognitively healthy older adults and their relationship to cognitive performance and depressive symptoms. Journal of Alzheimer's Disease, 59(3), 871-881.

Miller, G.A. \& Chapman, J.P. (2001). Misunderstanding analysis of covari- 
ance. Journal of Abnormal Psychology, 110(1), 40-48.

Mitchell, A. J., Beaumont, H., Ferguson, D., Yadegarfar, M., \& Stubbs, B. (2014). Risk of dementia and mild cognitive impairment in older people with subjective memory complaints: meta-analysis. Acta Psychiatrica Scandinavica, 130(6), 439-451.

Na, D. L. (2016). Cognitive Neurology and Neuropsychology for Clinicians. (pp.75-98). Seoul: Wisdomhouse.

Nam, K. C., Seo, K J., Choi, K. S., Lee, K. G., Kim, T. H., \& Lee, M. Y. (1997). The word length effect on Hangul word recognition. Korean Journal of Experimental and Cognitive Psychology, 9(2), 1-18.

Paul, R. \& Norbury, C. (2012). Language Disorders from Infancy Through Adolescence-E-Book: Listening, Speaking, Reading, Writing, and Communicating. (4th ed.), (p.522). St. Louis, MO: Elsevier Health Sciences.

Petersen R. C. (2004). Mild cognitive impairment as a diagnostic entity. Journal of Internal Medicine, 256(3), 183-194.

Petersen, R. C., Smith, G. E., Waring, S. C., Ivnik, R. J., Tangalos, E. G., \& Kokmen, E. (1999). Mild cognitive impairment: clinical characterization and outcome. Archives of Neurology, 56(3), 303-308.

Pettersson, A. F., Olsson, E., \& Wahlund, L. O. (2005). Motor function in subjects with mild cognitive impairment and early Alzheimer's disease. Dementia and Geriatric Cognitive disorders, 19(5-6), 299-304.

Rapcsak, S. Z., Arthur, S. A., Bliklen, D. A., \& Rubens, A. B. (1989). Lexical agraphia in Alzheimer's disease. Archives of Neurology, 46(1), 6568.

Rosenblum, S., Samuel, M., Zlotnik, S., Erikh, I., \& Schlesinger, I. (2013). Handwriting as an objective tool for Parkinson's disease diagnosis. Journal of Neurology, 260(9), 2357-2361.

Ryu, J. M., Kim, K. W., Park, J. H., Lee, S. B., Choi, E. A., Choe, J. Y., et al. (2007). Predictors for Subjective Memory Complaints in the Elderly: The Results from Korean Longitudinal Study on Health and Aging
(KLoSHA). Journal of Korean Neuropsychiatric Association, 46(6), 560-565.

Shin, J. Y. \& Cha, J. E. (2003). Korean Sound System. Seoul: Hangukmunwhasa.

Song, M. \& Kang, Y. (2011). Characteristics of memory complaints, cognitive function, and emotion in subjective memory impairment. Dementia and Neurocognitive Disorders, 10(4), 125-136.

Tompkins, G. E. (2002). Struggling readers are struggling writers, too. Reading and Writing Quarterly, 18(2), 175-193.

Won, S. R., Yoon, J. H., \& Na, D. L. (2017). Characteristics of confrontation naming ability according to word frequency in patients with amnestic mild cognitive impairment: A preliminary study. Communication Sciences and Disorders, 22(2), 177-189.

Yoon, J. H., Jeong, Y., \& Na, D. L. (2018). Medial-vowel writing difficulty in Korean syllabic writing: A characteristic sign of Alzheimer's disease. Journal of Clinical Neurology, 14(2), 179-185.

Yoon, J. H., Kim, H., Seo, S. W., Chin, J., Kim, J. H., Lee, K. H., et al. (2012). Dysgraphia in Korean patients with Alzheimer's disease as a manifestation of bilateral hemispheric dysfunction. Journal of the Neurological Sciences, 320(1-2), 72-78.

Yoon, J. H. \& Lee, E. O. (2014). Characteristics of orthographic retrieval with age in the elderly. Phonetics and Speech Sciences, 6(1), 119-125.

Yoon, J. H., Na, D. L., \& Kim, H. (2009). Agraphia in dementia. Dementia and Neurocognitive Disorders, 8(1), 1-14.

Yoon, J. H., Shin, J. C., Kim, D. Y., Suh, M. K., \& Kim, H. (2006). Korean agraphia subsequent to right hemispheric lesion. Speech Sciences, 13(3), 121-132.

Yoon, J. H., Suh, M. K., Jeong, Y., Ahn, H. J., Moon, S. Y., Chin, J., et al. (2011). Agraphia in Korean patients with early onset Alzheimer's disease. International Psychogeriatrics, 23(8), 1317-1326. 


\section{APPENDIX}

\section{List of word [Pronunciation] (Phonological rules)}

\begin{tabular}{ccc}
\hline Regular word & Phoneme-grapheme noncorrespondent word & Nonword \\
\hline 뺨 & 칡[칙] (자음군 단순화) & 콴 \\
꿩 & 덫[덛] (평폐쇄음화) & 웍 \\
귤 & 몫[목] (자음군 단순화) & 톰 \\
용 & 솥[솓] (평폐쇄음화) & 줍 \\
완성 & 맏형[마텽] (격음화) & 판십 \\
표범 & 법률[범뉼] (비음화) & 고돈 \\
주사위 & 등받이[등바지] (구개음화) & 물버건 \\
과수원 & 넚두리[넉뚜리] (자음군 단순화, 경음화) & 눈별민 \\
\hline
\end{tabular}

